\title{
Scientific research in obstetrics and gynecology: changes in the trends over three decades
}

This article was published in the following Dove Press journal:

International Journal of Women's Health

16 December 2014

Number of times this article has been viewed

\section{Gamal A Kassem \\ Department of Obstetrics and Gynecology, Faculty of Medicine, Zagazig University, Zagazig, Egypt}

Correspondence: Gamal A Kassem Borg Al Seleem 3, Fourth Floor, Flat 6, Alqumia Street, Zagazig 44519, Egypt Tel +20 552353828

Email gamal-1960@hotmail.com
Aim: The aim of this work was to assess scientific research of master's and doctoral theses and essays in the Department of Obstetrics and Gynecology, Zagazig University, Egypt.

Materials and methods: All master's and doctoral theses and essays since the foundation of Department of Obstetrics and Gynecology, Zagazig University, Egypt, in 1975 till end of 2012 were reviewed.

Results: A total of 703 theses and essays were reviewed. The important topics in the specialty of obstetrics and gynecology were covered and updated. Infertility, in vitro fertilization-embryo transfer (IVF-ET) and related techniques, and polycystic ovarian disease were the most common gynecologic topics (27.2\%), followed by gynecologic oncology (18.5\%). Preeclampsia was the most common obstetrics topic (18.8\%), followed by issues of high-risk pregnancy, fetal growth restriction, and fetal well-being (11.6\%). The number of researches that allow the candidates to learn skills was 183 and it was increased from 4.4\% of all research in the period 1979-1988 to $33.2 \%$ in period $1989-2000$ then slightly decreased to $31.2 \%$ in period $2001-2012$. Ultrasonography was on the top and was present in 99 out of $183(54.1 \%)$ followed by laparoscopy $(30,16.4 \%)$, hysteroscopy $(25,13.7 \%)$, IVF-ET and related techniques $(16,8.7 \%)$ and colposcopy $(13,7.1 \%)$ researches. Multi-disciplinary research was decreased by $61.7 \%$ in the period 2001-2012. Researches in academic fields were abandoned and in some clinically important areas like preeclampsia were decreased.

Conclusion: Scientific research of master's and doctoral theses and essays was comprehensive, updated, and had some autonomy independent of plans. Research which enable the candidate to learn skills were increased on the expense of academic, clinical and multidisciplinary research. It could be recommended that plans for scientific research should be flexible and should leave a space for local departmental views. Proper training of residents during their rotation in these subspecialties may help to revive the lost interest in clinically important areas.

Keywords: obstetrics, gynecology, research, thesis, essay

\section{Introduction}

Active participation or submission of a scientific research is an essential step in residency or scholarship programs. ${ }^{1}$ Studies have noted that research improves analytical and communication skills of the candidates as well as lifelong learning. ${ }^{2}$ It was also observed that residents interested in research and publications have greater academic success. ${ }^{3,4}$

According to the rules of Supreme Council of Universities, Egypt, submitting a scientific research in the form of a thesis or an essay is one of the requirements to gain a master's or doctoral degree. Selection of the topic of the research is related to many factors such as availability of cases, instruments, subspecialty, and personal view 
of the supervising professor. The interest of the candidate is also important. In 2013, discussions started within the faculty to develop a plan for scientific research for the next 5 years. There was a need to review all research to get an impression about previous work. The aim of this study was to assess scientific research of theses and essays accepted in the Department of Obstetrics and Gynecology, Zagazig University, since its foundation in 1975 till end of 2012.

\section{Materials and methods}

This retrospective observational study was conducted at the Department of Obstetrics and Gynecology, Faculty of Medicine, Zagazig University, Egypt, from January to March 2013.

All accepted theses and essays since the foundation of the department in 1975 till end of 2012 were reviewed. The review included title of research, year of acceptance, and supervision from another department. Methodology and skills that the candidate should learn, such as ultrasonography, endoscopy, in vitro fertilization-embryo transfer (IVF-ET), and colposcopy, were checked. Assessment also included the influence of establishment of new specialized units on scientific research. For the sake of convenience, the term "research" will be used to refer to essays and theses in this study.

The Department of Obstetrics and Gynecology, Faculty of Medicine, Zagazig University, was founded in 1975 as a small department under the supervision of Ain-Shams University (the mother university). Then the department became separate and also grew larger. There was an increase in the number of beds, the number of undergraduate and postgraduate candidates, staff, and subsequently the number of research activities. The formation of specialized units of laparoscopy, hysteroscopy, IVF-ET, and ultrasound started in the first half of the 1990s. Colposcopy was present since 1980. A Gynecologic Oncology Unit was founded officially in the first half of 2000s. We have no gynecologic urology unit, although there are some preparations for it.

One of the requirements for a master's degree is to submit either a thesis or an essay. An essay is review article. For a doctoral degree, a thesis should be submitted. Each thesis or essay should have a supervising committee comprising a professor, assistant professor or lecturer(s), a system similar to mentorship. ${ }^{5}$ If part of the work will be done in another department, a supervisor from that department will also be part of the committee. According to rules in the university, supervision from another department is recommended, but is not obligatory. Candidates are encouraged to gain training and supervision from national and international experts in the field of the research.

The study was approved by the Obstetrics and Gynecology Council of the faculty. Data were represented as mean and standard deviation.

\section{Results}

A total of 703 theses and essays were reviewed. There were $575(81.8 \%)$ and $128(18.2 \%)$ theses and essays, respectively. The first thesis accepted was in 1977. Because the overall study included 36 years, this period was classified into three parts, each part comprising 12 years (Figure 1). The number of topics in gynecology and obstetrics were 367 and 336, respectively (Tables 1 and 2). Infertility was the most common topic in gynecology. Topics were updated from basic investigations like hysterosalpingography to different techniques of artificial insemination (AI) and IVF-ET. Research also evaluated different parameters of ovarian reserve and its relation to the outcome of IVF. As regards to polycystic ovarian disease (PCOD), research included diagnostic, biochemical, ultrasonographic criteria, and role of insulin sensitizers. Research in gynecologic oncology included recent aspects of diagnosis and treatment of different gynecologic tumors. Role of laparoscopy in characterization of adnexal masses, management of large ovarian cysts, hysterectomy, and pelvic lymphadenectomy in early cancer cervix are examples. Research also covered new tumor markers like human epididymis protein 4 . The relation between human papilloma virus and genital tract malignancy was also studied. Ultrasound and color Doppler were used to predict depth of myometrial invasion in cancer endometrium.

Preeclampsia was the first topic in obstetrics, and research included prediction, pathogenesis, clinical criteria, and laboratory investigations. Use of ultrasound and color Doppler was extensive.

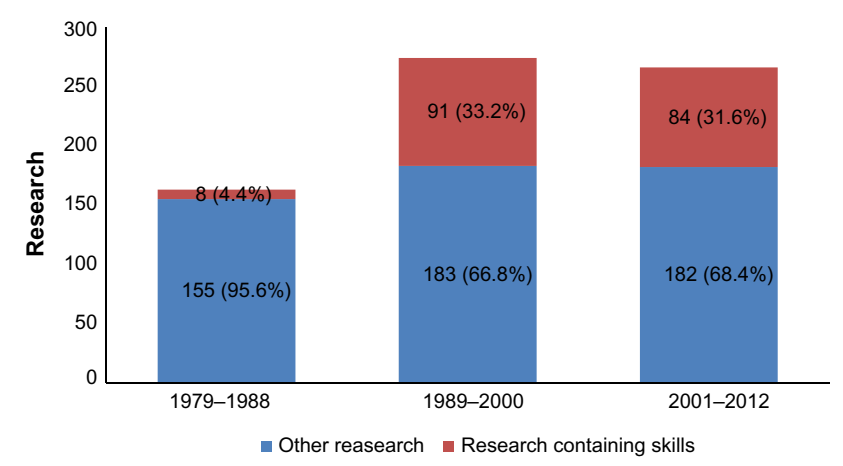

Figure I Number of research that contain skills in relation to total research in obstetrics and gynecology over 36 years in Zagazig University $(\mathrm{N}=703)$. 
Table I Gynecological topics involved in theses and essays in relation to year of acceptance $(\mathrm{N}=367)$

\begin{tabular}{|c|c|c|c|c|}
\hline Topic & $\begin{array}{l}1977- \\
1988\end{array}$ & $\begin{array}{l}1989- \\
2000\end{array}$ & $\begin{array}{l}2001- \\
2012\end{array}$ & $\begin{array}{l}\text { Total } \\
\text { N (\%) }\end{array}$ \\
\hline Infertility, IVF-ET, PCOD & 15 & 37 & 48 & $100(27.2)$ \\
\hline Gynecologic oncology & 11 & 16 & 41 & $68(18.5)$ \\
\hline Contraception & 30 & 24 & 13 & $67(18.3)$ \\
\hline Abnormal uterine bleeding & 7 & 14 & 12 & $33(9)$ \\
\hline Genital tract infection & 12 & 9 & I & $22(6)$ \\
\hline $\begin{array}{l}\text { Uro-gynecology, } \\
\text { genital prolapse }\end{array}$ & 3 & 4 & 8 & $15(4.1)$ \\
\hline Menopause and HRT & 3 & 3 & 9 & $15(4.1)$ \\
\hline $\begin{array}{l}\text { Endometriosis, pelvic pain, } \\
\text { dysmenorrhea }\end{array}$ & 2 & 3 & 3 & $8(2.2)$ \\
\hline $\begin{array}{l}\text { Physiology, anatomy, } \\
\text { congenital malformations }\end{array}$ & 5 & I & 0 & $6(1.6)$ \\
\hline Uterine fibroids & 0 & 0 & 5 & $5(1.4)$ \\
\hline Others & 4 & 14 & 10 & $28(7.6)$ \\
\hline Total & 92 & 125 & 150 & $367(100)$ \\
\hline
\end{tabular}

Abbreviations: IVF-ET, in vitro fertilization-embryo transfer; PCOD, polycystic ovarian disease; HRT, hormone replacement therapy.

Table 2 Obstetrical topics involved in the theses and essays in relation to the year of acceptance $(\mathrm{N}=336)$

\begin{tabular}{|c|c|c|c|c|}
\hline Topic & $\begin{array}{l}1977- \\
1988\end{array}$ & $\begin{array}{l}1989- \\
2000\end{array}$ & $\begin{array}{l}2001- \\
2012\end{array}$ & $\begin{array}{l}\text { Total } \\
\text { N (\%) }\end{array}$ \\
\hline Preeclampsia & 11 & 31 & 21 & $63(18.8)$ \\
\hline $\begin{array}{l}\text { High-risk pregnancy, } \\
\text { FGR, fetal well being }\end{array}$ & 7 & 21 & 11 & $39(11.6)$ \\
\hline $\begin{array}{l}\text { Spontaneous abortion, } \\
\text { RPL, induction of abortion }\end{array}$ & 9 & 15 & 7 & $31(9.2)$ \\
\hline Preterm labor, PROM & 3 & 11 & 15 & $29(8.6)$ \\
\hline $\begin{array}{l}\text { CS, VBAC, instrumental } \\
\text { delivery }\end{array}$ & 8 & 8 & 9 & $25(7.4)$ \\
\hline Prolonged pregnancy, IOL & 2 & 10 & 9 & $21(6.3)$ \\
\hline $\begin{array}{l}\text { Diabetes, obesity with } \\
\text { pregnancy }\end{array}$ & 4 & 7 & 7 & $18(5.4)$ \\
\hline $\begin{array}{l}\text { Labor and delivery } \\
\text { and neonate }\end{array}$ & 5 & 8 & 3 & $16(4.8)$ \\
\hline $\begin{array}{l}\text { APH: placenta previa, } \\
\text { accidental hemorrhage }\end{array}$ & 3 & 3 & 6 & $12(3.6)$ \\
\hline Urinary tract with pregnancy & 5 & 3 & 2 & $10(3)$ \\
\hline $\begin{array}{l}\text { Genetics, fetal physiology, } \\
\text { malformations, medicine }\end{array}$ & 1 & 1 & 9 & II (3.3) \\
\hline $\begin{array}{l}\text { Physiology, experimental, } \\
\text { colposcopy }\end{array}$ & 1 & 7 & 1 & $9(2.7)$ \\
\hline Puerperal issues & 2 & 5 & 0 & $7(2.1)$ \\
\hline $\begin{array}{l}\text { Postpartum hemorrhage } \\
\text { and collapse }\end{array}$ & 2 & 2 & 3 & $7(2.1)$ \\
\hline Infection with pregnancy & 2 & 3 & I & $6(1.8)$ \\
\hline Anemia with pregnancy & 3 & 2 & 0 & $5(1.5)$ \\
\hline Maternal/perinatal mortality & I & 3 & 0 & $4(1.2)$ \\
\hline Others & 2 & 9 & 12 & $23(6.8)$ \\
\hline Total & 71 & 149 & 116 & $336(100)$ \\
\hline
\end{tabular}

Abbreviations: FGR, fetal growth restriction; RPL, recurrent pregnancy loss; PROM, prelabor rupture of membranes; CS, cesarean section; VBAC, vaginal birth after cesarean; IOL, induction of labor; APH, antepartum hemorrhage.
Theses including skills were 183, which represented $31.8 \%$ of theses and $26 \%$ of all research. As shown in Figure 1, the numbers increased from 8 of $163(4.4 \%)$ in the period 1979-1989 to 91 of 274 (33.2\%) in the period $1989-2000$, and then slightly decreased to 84 of $266(31.2 \%)$ in the period 2001-2012. Ultrasonography was the most common topic (99 theses, 54.1\%) followed by laparoscopy $(30,16.4 \%)$, hysteroscopy $(25,13.7 \%)$, AI, IVF-ET, and related techniques $(16,8.7 \%)$, and lastly colposcopy (13 theses, 7.1\%) (Figure 2). Ultrasonography and color Doppler research included prediction, pathogenesis of preeclampsia as well as prediction, diagnosis, and monitoring of fetal growth restrictions. In preterm labor, ultrasonography was used in the prediction of preterm labor by measuring cervical length. Theses also included diagnostic criteria of placenta accreta. In abnormal uterine bleeding, ultrasound was used in evaluation of uterine cavity. In addition hydrosonography was also used in comparison to hysteroscopy. Techniques involved transabdominal, transvaginal, and transperineal examinations.

Research in laparoscopy included infertility, ovarian drilling for PCOD, and different techniques of laparoscopic hysterectomy. In hysteroscopy, theses included comparison between hysteroscopy and hysterosalpingography, as well as comparison between $\mathrm{CO}_{2}$ and normal saline as distending medium. Hysteroscopy also used before and after failed IVF-ET. Operative hysteroscopy included monopolar and bipolar resectoscopic surgery. Research also included salpingoscopy and fallopian tube catheterizations.

Supervisions from another department in our faculty were present in 297 theses (Table 3). Supervision from other universities (national experts) was noted in 10 theses, and international experts in 7 theses. The total supervisions

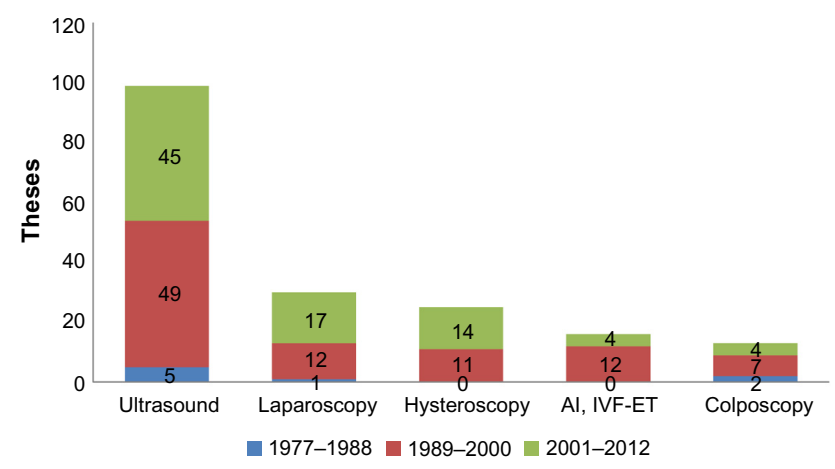

Figure 2 Number of theses that contain skills in obstetrics and gynecology over 36 years in Zagazig University $(\mathrm{N}=183)$.

Abbreviations: Al, artificial insemination; IVF-ET, in vitro fertilization-embryo transfer. 
Table 3 Supervision from other departments (same university) $(\mathrm{N}=297)$

\begin{tabular}{|c|c|c|c|c|}
\hline Department & $\begin{array}{l}1977- \\
1988\end{array}$ & $\begin{array}{l}1989- \\
2000\end{array}$ & $\begin{array}{l}2001- \\
2012\end{array}$ & $\begin{array}{l}\text { Total } \\
\text { N (\%) }\end{array}$ \\
\hline Clinical pathology & 13 & 29 & 13 & $55(18.5)$ \\
\hline Microbiology & 22 & 32 & 7 & $54(18)$ \\
\hline Pathology & 18 & 21 & 11 & $50(16.8)$ \\
\hline Radiology & 9 & 23 & 10 & 44 (I4.8) \\
\hline Biochemistry & 6 & 15 & 8 & $29(9.7)$ \\
\hline Community medicine & 8 & 6 & 2 & $16(5.3)$ \\
\hline $\begin{array}{l}\text { Radiobiochemistry (for radio } \\
\text { immunoassay of hormones) }\end{array}$ & 5 & 2 & 0 & $7(2.3)$ \\
\hline Physiology & 5 & 2 & 0 & $7(2.3)$ \\
\hline Histology & 4 & 0 & I & $5(1.6)$ \\
\hline Urosurgery & I & 2 & I & $4(1.3)$ \\
\hline Anesthesia & 0 & 3 & I & $4(1.3)$ \\
\hline Pediatrics & 2 & I & 0 & $3(1)$ \\
\hline Cardiology & 2 & I & 0 & $3(1)$ \\
\hline Anatomy & 2 & I & 0 & $3(1)$ \\
\hline Ear, nose, and throat & 2 & 0 & 0 & $2(0.6)$ \\
\hline Parasitology & 2 & 0 & 0 & $2(0.6)$ \\
\hline Rheumatology & 0 & I & 0 & $\mathrm{I}(0.3)$ \\
\hline Psychiatry & 0 & I & 0 & $\mathrm{I}(0.3)$ \\
\hline Internal medicine & 0 & I & 0 & $\mathrm{I}(0.3)$ \\
\hline Ophthalmology & I & 0 & 0 & I $(0.3)$ \\
\hline Total & 102 & 141 & 54 & $297(100)$ \\
\hline
\end{tabular}

beyond our department were present in 314 cases, which represent $54.7 \%$ of theses (Tables 3-5).

\section{Discussion}

This study shows that scientific research included in theses and essays for the master's and doctoral degrees was comprehensive. Important topics in the specialty of obstetrics and gynecology were covered. Infertility was the most common topic in gynecology, followed by gynecologic oncology. Both topics represented about half of all theses and essays in gynecology. Preeclampsia was the most common obstetrics topic (18.8\%), followed by issues of high-risk pregnancy, fetal growth restriction, and fetal well-being (11.6\%). The study also shows that scientific research was updated. This was more evident regarding infertility research. We observed that not only the number

Table 4 Supervision from another university (national experts) $(\mathrm{N}=10)$

\begin{tabular}{lc}
\hline Skill/subspecialty & $\mathbf{N}$ \\
\hline IVF-ET & 3 \\
Gynecologic oncology & 2 \\
Operative laparoscopy (laparoscopic mesh for vault prolapse) & $\mathrm{I}$ \\
Ultrasonography & $\mathrm{I}$ \\
Colposcopy & 2 \\
Cytogenetics of recurrent pregnancy loss & $\mathrm{I}$ \\
\hline
\end{tabular}

Abbreviation: IVF-ET, in vitro fertilization-embryo transfer.
Table 5 Supervision from outside Egypt (international experts), $(\mathrm{N}=7)$

\begin{tabular}{lll}
\hline Country & Skill-subspecialty & $\mathbf{N}$ \\
\hline USA & Use of laser in microsurgery & I \\
USA & Gynecologic oncology, histochemistry of CIN & I \\
USA & $\begin{array}{l}\text { Gynecologic oncology (HPV and oncogencity } \\
\text { of lower genital tract) }\end{array}$ & I \\
Canada & Gynecologic oncology & I \\
USA & IVF-ET & I \\
Italy & Hysteroscopy & I \\
USA & Management of the menopause & I
\end{tabular}

Abbreviations: $\mathrm{CIN}$, cervical intraepithelial neoplasia; HPV, human papilloma virus; IVF-ET, in vitro fertilization-embryo transfer.

of researches in infertility was steadily increased but also the topics were updated. Issues of AI, IVF-ET and related techniques, ovarian reserve, and role of endoscopy were covered. Recent research areas on PCOD were also studied. Actually, infertility became a well-established subspecialty mainly due to marked advancement in IVF-ET and related techniques in last three decades. ${ }^{6,7}$

We observed that there was a marked increase in the number of researches after establishment of specialized units of ultrasonography, endoscopy and IVF-ET (Figure 1). This was more evident for research using ultrasound. As shown in Figure 2, theses including ultrasound jumped from five in the period 1977-1988 to 49 in the period 1989-2000. Actually, advances in technology have expanded the field of obstetrics and gynecology and made training and developing skills in different subspecialties a great challenge. ${ }^{8,9}$ It seems that candidates preferred scientific research that enabled them to gain skills, and ultrasonography represented the first choice. Ultrasonography is relatively easy to learn, with great application in clinical practice. ${ }^{10}$ Similar increase, but to a lesser extent, occurred in research in field of laparoscopy and hysteroscopy. The least number of researches were observed in the field of colposcopy. This could be explained by the absence of any national program for screening of cervical cancer. Actually, cervical cancer is not a great health problem in Egypt. ${ }^{11}$ Similar findings were observed regarding research in gynecologic oncology which was increased by 1.5 times in the last 12 years with the establishment of the Gynecologic Oncology Unit.

Multidisciplinary collaboration in research is important. It improves research quality, increases research output, and also improves the communication skills of the researchers. ${ }^{12,13}$ In the present study, more than half of the theses had supervision from another department, either academic or clinical. However, as shown in Table 3 , there was a reduction in the number of supervisions from 141 to $45(61.7 \%)$ in the 
last 12 years. This may be explained by a decreased interest in academic research such as anatomy, physiology, and experimental work. The interest in ultrasound, laparoscopy, and hysteroscopy is clear, even though research in some clinically important areas like preeclampsia was also decreased (Tables 1 and 2). Therefore, proper training of residents during their rotation in these subspecialties may help to revive the lost interest in clinically important areas.

The strength of this study is that it reviewed all master and doctoral theses and essays conducted through 36 years. This long period makes the results about changes in trends in research reliable and makes study beneficial for planning of scientific research and training of residents in obstetrics and gynecology. However, the study did not include other research published by staff members for promotion to the posts of professors. Actually, some staff members research are based on these master and doctoral theses. Therefore the study is typically concerned with research done by masters and doctoral candidates but still represents the scientific research in obstetrics and gynecology.

\section{Conclusion}

In conclusion, scientific research of master's and doctoral theses and essays was comprehensive, updated, and had some autonomy independent of plans. Research which enable the candidate to learn skills were increased on the expense of academic, clinical and multidisciplinary research. It could be recommended that plans for scientific research should be flexible and should leave a space for local departmental views. Proper training of residents during their rotation in these subspecialties may help to revive the lost interest in clinically important areas.

\section{Acknowledgments}

The author thanks Professor Mohammed M Al-bakry, exHead of Department of Obstetrics and Gynecology, and Professor Monqez Motea, Vice Dean and Head of Scientific
Research Council, Faculty of Medicine, Zagazig University, for their great support and encouragement. The author also thanks Dr Reem Abbas, Professor in Community Medicine, for her advice regarding the statistics used for the study.

\section{Disclosure}

The author reports no conflict of interest in this work.

\section{References}

1. Sulak PJ, Croop JA, Hillis A, Kuehl TJ. Resident research in obstetrics and gynecology: development of a program with comparison to a national survey of residency programs. Am J Obstet Gynecol. 1992;167: 498-502.

2. Turnberg LA. The place of research in the training of NHS physicians consultants. J R Coll Physicians Lond. 1993;27:400-404.

3. Reulen HJ. The role of research in the training of residents. Eur Surg Res. 2002;34:13-17.

4. Hsieh H, Paquette F, Fraser, SA, et al. Formal research training during surgical residency: scaffolding for academic success. Am J Surg. 2014;207:141-145.

5. Cohen JG, Sherman AE, Kiet TK, et al. Characteristics of success in mentoring and research productivity - a case-control study of academic centers. Gynecol Oncol. 2012;125(1):8-13.

6. Wang J, Sauer MV. In vitro fertilization (IVF): review of 3 decades of clinical innovation and technological advancement. Ther Clin Risk Manag. 2006;2(4):335-364.

7. Chai J, Yeung TW, Lee VC, et al. Live birth rate, multiple pregnancy rate, and obstetric outcomes of elective single and double embryo transfers: Hong Kong experience. Hong Kong Med J. 2014;20(2): $102-106$.

8. Risso-Gill I, Kiasuwa R, Baeten R, et al. Exploring the scope of practice and training of Obstetricians and Gynaecologists in England, Italy and Belgium: a qualitative study. Eur J Obstet Gynecol Reprod Biol. 2014;180:40-45.

9. Arendas K, Posner GD, Singh SS. Managing expectations of surgical training: a national perspective on gynecologic endoscopy practice. J Obstet Gynaecol Can. 2013;35(7):640-646.

10. Datta S. Ultrasound in obstetrics and gynecology. Obstet Gynaecol Reprod Med. 2013;23(7):202-207.

11. ICO Information Centre on HPV and Cancer. Human Papillomavirus and Related Cancers, Egypt Fact Sheet 2013. Barcelona, Spain: ICO Information Centre on HPV and Cancer; January 31, 2014.

12. Vincent C, Batalden P, Davidoff F. Multidisciplinary centers for safety and quality improvement learning from climate science. BMJ Qual Saf. 2011;20(Suppl 1):i73-i78. doi:10.1136/bmjqs.2010.047985.

13. Clark AM, Narine KA, Hsu ZY, et al. Preparing today's cardiovascular trainees to meet the challenges of tomorrow: team research and interdisciplinary training. Can J Cardiol. 2014;30(6):683-686.
International Journal of Women's Health

\section{Publish your work in this journal}

The International Journal of Women's Health is an international, peerreviewed open-access journal publishing original research, reports, editorials, reviews and commentaries on all aspects of women's healthcare including gynecology, obstetrics, and breast cancer. The manuscript management system is completely online and includes

\section{Dovepress}

a very quick and fair peer-review system, which is all easy to use. Visit http://www.dovepress.com/testimonials.php to read real quotes from published authors. 